\title{
EFEKTIVITAS MODEL PEMBELAJARAN DISCOVERY LEARNING UNTUK MENINGKATKAN KETERAMPILAN BERPIKIR KRITIS SISWA PADA MATERI SISTEM KOLOID
}

\author{
Yattinah Hidayat $^{* 1}$, Jofrishal ${ }^{2}$ dan Seprianto ${ }^{3}$ \\ ${ }^{1,2,3}$ Program Studi Pendidikan Kimia, FKIP Universitas Samudra \\ Jln. Kampus Meurandeh, Langsa - Aceh 24416 \\ *Email: tinahidayat2401@gmail.com
}

\begin{abstract}
ABSTRAK
Penelitian ini bertujuan mengetahui efektivitas model pembelajaran discovery learning terhadap peningkatan keterampilan berpikir kritis siswa pada materi sistem koloid dan mengetahui keterlaksanaan model pembelajaran discovery learning. Penelitian ini menggunakan metode quasi eksperimen dengan desain pretest-posttest control group. Populasi dalam penelitian ini adalah seluruh siswa kelas XI IPA di MAN 1 Langsa tahun pelajaran 2018/2019. Teknik pengambilan sampel dilakukan dengan teknik cluster random sampling sehingga didapatkan 2 kelas sampel yaitu kelas eksperimen dan kelas kontrol. Instrumen yang digunakan untuk mengukur keterampilan berpikir kritis siswa yaitu tes berbentuk uraian pada materi sistem koloid. Keefektifan model pembelajaran discovery learning dilihat dari $n$-Gain, uji perbedaan rata-rata, dan uji ukuran pengaruh. Nilai $n$-Gain yang diperoleh pada kelas eksperimen sebesar 0,77 dan kelas kontrol sebesar 0,66, yang artinya peningkatan keterampilan berpikir kritis siswa pada kelas eksperimen dan kelas kontrol tergolong dalam kriteria sedang. Hasil uji perbedaan rata-rata menunjukkan bahwa nilai $t_{\text {hitung }}(2,89) \geq \mathrm{t}_{\text {tabel }}(1,68)$, sehingga $\mathrm{H}_{0}$ ditolak, yang artinya peningkatan keterampilan berpikir kritis siswa pada kelas eksperimen lebih tinggi secara signifikan dibandingkan siswa pada kelas kontrol. Hasil analisis ukuran pengaruh menunjukkan bahwa nilai $\mu$ yang diperoleh sebesar 0,96 yang artinya efek model discovery learning terhadap peningkatan keterampilan berpikir kritis siswa tergolong kategori besar. Berdasarkan nilai $n$ Gain, uji perbedaan rata-rata, dan uji ukuran pengaruh, maka dapat disimpulkan bahwa pembelajaran dengan model discovery learning lebih efektif dalam meningkatkan keterampilan berpikir kritis siswa pada materi sistem koloid dibandingkan pembelajaran yang tidak menggunakan model discovery learning. Keterlaksanaan model pembelajaran discovery learning pada materi sistem koloid di kelas XI IPA MAN 1 Langsa terlaksana dengan baik, dengan tingkat ketercapaian guru dalam mengelola pembelajaran pada setiap pertemuannya berturutturut sebesar $73,80 \%, 79,10 \%$, dan $85,70 \%$. Sedangkan pada aktivitas siswa pada saat pembelajaran tiap pertemuannya berturut-turut sebesar 100\%, 91,70\%, dan 94,43\%.
\end{abstract}

Kata Kunci: efektivitas, discovery learning, keterampilan berpikir kritis, sistem koloid

\section{ABSTRACT}

This study aims to determine the effectiveness of discovery learning models on improving students' critical thinking skills on colloid system material and knowing the implementation of discovery learning learning models. This study uses a quasi-experimental method with a pretestposttest control group design. The population in this study were all students of class XI IPA in MAN 1 Langsa in the 2018/2019 academic year. The sampling technique was done by cluster random sampling technique so that get 2 sample classes, namely the experimental class and the 
control class. The instrument used to measure students' critical thinking skills is a test in the form of a description of the colloid system material. The effectiveness of discovery learning model is seen based on n-Gain, average difference test, and effect size test. The n-Gain value obtained in the experimental class was 0.77 and the control class was 0.66, which means that the increase in students' critical thinking skills in the experimental class and the control class belonged to the medium criteria. The average difference test results showed that the value of $t_{\text {count }}(2.89) \geq t_{\text {table }}(1.68)$, so that $H_{0}$ was rejected, which means that the increase in students' critical thinking skills in the experimental class was significantly higher than students in the control class. The results of the analysis of the effect size show that the $\mu$ value obtained is 0.96 , which means the effect of the discovery learning model on improving students' critical thinking skills is in a large category. Based on the n-Gain value, average difference test, and effect size test, then can concluded that learning with discovery learning models is more effective in improving students' critical thinking skills on colloid system material compared to learning that does not use discovery learning models. The implementation of the discovery learning model in the colloid system material in class XI IPA MAN 1 Langsa is well implemented, with the level of teacher achievement in managing learning at each meeting successively at $73.80 \%, 79.10 \%$, and $85.70 \%$. Whereas the activities of students during the learning session were 100\%, $91.70 \%$, and $94.43 \%$ respectively.

\section{Keywords: effectiveness, discovery learning, critical thinking skills, colloid system}

\section{PENDAHULUAN}

Abad 21 sering diistilahkan sebagai abad pengetahuan (Santyasa, 2018). Dalam menghadapi era globalisasi di Abad 21, siswa perlu dibekali dengan pengetahuan dan kecakapan untuk hidup di masa sekarang dan masa depan, salah satunya melalui pembelajaran abad 21. Pembelajaran Abad 21 adalah pembelajaran yang mampu menjadikan siswa memiliki kecakapan yaitu berupa kecakapan karakter, kompetensi, dan literasi (Wati, 2018). Kemendikbud (2013) merumuskan bahwa paradigma pembelajaran abad 21 menekankan pada kemampuan siswa dalam mencari tahu dari berbagai sumber, merumuskan permasalahan, berpikir analitis dan kerjasama serta berkolaborasi dalam menyelesaikan masalah. Partnership for 21st Century Skills menekankan bahwa pembelajaran abad 21 harus mengajarkan 4 kompetensi yaitu komunikasi, kolaborasi, berpikir kritis, dan berpikir kreatif (Hidayah, Salimi, dan Susiana, 2017). Hal ini juga sesuai dengan Assessment \& Teaching of 21st Century Skills (ATC21S) (dalam Arifin, 2017) yang menyatakan bahwa mengelompokkan kecakapan abad 21 dalam 4 kategori, salah satunya adalah cara berpikir. Lloyd dan Bahr (2010) menyatakan bahwa salah satu tujuan utama pendidikan saat ini di antaranya pengembangan kemampuan berpikir kritis.

Ennis (1995) menyatakan bahwa berpikir kritis adalah cara berpikir logis dan masuk akal yang difokuskan pada pengambilan keputusan tentang apa yang dipercaya dan dilakukan. Hal ini senada dengan yang diungkapkan Yasushi Gotoh (2016) bahwa "critical thinking as the set of skills and dispositions which enable one to solve problems logically and to attempt to reflect autonomously by means of Metacognitive regulation on one's own problem-solving processes". Dengan kata lain, berpikir kritisadalah seperangkat keterampilan dan kecenderungan yang memungkinkan seseorang untuk memecahkan masalah secara logis. Keterampilan berpikir kritis juga dapat diartikan kemampuan berpikir seseorang dalam mengambil keputusan Facione,Facione, dan Sanchez (2010) menyatakan bahwa berpikir kritis adalah proses membuat penilaian yang beralasan berdasarkan pertimbangan bukti yang 
tersedia, aspek kontekstual dari suatu situasi, dan konsep-konsep terkait. Sedangkan menurut Redecker (dalam Muin, 2018; Hidayahdkk.,2017), keterampilan berpikir kritis mencakup kemampuan mengakses, menganalisis, mensintesis informasi yang dapat dibelajarkan, dilatihkan dan dikuasai.

Salah satu pembelajaran yang menuntut siswa untuk berpikir kritis adalah pembelajaran kimia. Kristaliningtyas, Utomo, dan Yamtinah (2018) menyatakan bahwa pembelajaran kimia yang diterapkan di sekolah-sekolah masih berpusat pada guru (teacher centered) bukan berpusat pada siswa (student centered).

Berdasarkan observasi yang telah dilakukan di MAN 1 Langsa, pembelajaran kimia masih berlangsung satu arah dari guru ke siswa. Guru hanya berceramah menjelaskan materi sementara siswa hanya mendengarkan ceramah dan mencatat materi yang telah disampaikan oleh guru. Pembelajaran tersebut tidak mengembangkan keterampilan berpikir kritis siswa. Hal ini sesuai dengan penelitian Pratiwi, Hairida, dan Rasmawan (2014) yang menyimpulkan bahwa yang selama ini sering diterapkan guru belum mengoptimalkan keterampilan berpikir kritis siswa.

Salah satu bentuk pembelajaran yang dapat mengembangkan keterampilan berpikir kritis siswa adalah model pembelajaran discovery learning (Pratiwi dkk., 2014; Masrida, Hala, dan Taiyeb, 2016; Fidiana, Rudibyani, dan Tania, 2018). Bruner (1997) menyatakan bahwa model discovery learning adalah metode belajar yang mendorong siswa untuk mengajukan pertanyaan dan menarik kesimpulan dari prinsip-prinsip umum praktis contohnya pengalaman. Purwanto (2012) menyatakan bahwa model discovery learning merupakan kegiatan pembelajaran yang melibatkan secara maksimal seluruh kemampuan berpikir siswa untuk mencari dan menemukan informasi untuk memecahkan masalah yang dihadapinya secara kritis, logis, dan analitis sehingga mereka dapat merumuskan sendiri penemuannya. Sementara itu, Masrida dkk. (2016) mengemukakan bahwa model pembelajaran discovery merupakan model mengajar yang me nitikberatkan pada aktivitas siswa dalam belajar. Pembelajaran discovery memiliki kelebihan yaitu menjadikan siswa lebih aktif dalam pembelajaran, siswa dapat memahami benar konsep yang telah dipelajari, jawaban yang diperoleh akan menimbulkan rasa puas pada siswa (Purwanto, 2012). Menurut Widiadnyana (dalam Masrida dkk., 2016) model pembelajaran discovery dapat menimbulkan rasa senang pada siswa karena membangkitkan keingintahuan siswa, memotivasi siswa untuk bekerja terus sampai menemukan jawaban.

Koloid merupakan salah satu materi yang dipelajari oleh siswa kelas XI IPA SMA pada semester genap. Kompetensi dasar yang terdapat dalam pembelajaran koloid adalah menganalisis peran koloid dalam kehidupan berdasarkan sifatnya dan mengajukan ide gagasan untuk memodifikasi pembuatan koloid berdasarkan pengalaman membuat beberapa jenis koloid (Purba, Rosilawati, dan Eftar, 2016). Materi koloid adalah materi hafalan yang menuntut siswa untuk mengembangkan nalar dan pengembangan konsep yang dasar menjadi konsep koloid itu sendiri (Ariani, Rasmiwetti, dan Haryati, 2018). Untuk itu, perlu diterapkan suatu model pembelajaran yang dapat meningkatkan keterampilan berpikir kritis siswa pada materi koloid.

Berdasarkan uraian di atas, peneliti termotivasi untuk mengadakan penelitian dengan judul: "Efektivitas Model Pembelajaran Discovery Learning untuk Meningkatkan Keterampilan Berpikir Kritis Siswa Pada Materi Sistem Koloid”.

\section{METODE PENELITIAN}

Lokasi penelitian dilaksanakan di MAN 1 Langsa. Waktu penelitian dilakukan selama 1 bulan terhitung mulai dari April sampai dengan Mei tahun 2019 pada semester genapTahun Pelajaran 2018/2019 di kelas XI IPA.

Penelitian ini merupakan jenis penelitian kuantitatif dengan menggunakan 
metode quasi eksperimen. Desain penelitian ini menggunakan pretest-posttest control group design. Pada desain ini, dilakukan dua kali tes yaitu pretest dan posttest pada kelompok eksperimen dan kelompok kontrol.

Populasi dalam penelitian ini adalah seluruh siswa kelas XI IPA Semester Genap MAN 1 Langsa Tahun Pelajaran 2018/2019 yang berjumlah 78 siswa.Sampel dalam penelitian ini terdiri dari dua kelas yaitu kelas XI IPA 1 sebagai kelas eksperimen yang berjumlah 20 siswa, dan kelas XI IPA 2 sebagai kelas kontrol yang berjumlah 20 siswa. Kelas eksperimen dan kelas kontrol diambil dengan teknik Cluster Random Sampling, yaitu teknik pengambilan sampel dari populasi dilakukan secara acak tanpa memperhatikan strata yang ada dalam populasi itu(Sugiyono, 2010).

Data dalam penelitian ini diperoleh dengan metode pengumpulan data berupa tes, observasi dan dokumentasi. Instrumen tes yang digunakan yaitu soal pretest- posttest dalam bentuk uraian (essay) yang terdiri atas 10 butir soal. Pretest diberikan pada kelas eksperimen dan kelas control untuk mengetahui kemampuan awal. Pada kelas eksperimen diberikan perlakuan berupa penerapan model pembelajaran discovery learning. Sedangkan pada kelas control tidak diberikan perlakuan penerapan model pembelajaran discovery learning dengan sebelumnya memastikan kedua kelas homogen pada keadaan awal perlakuan. Setelah itu, dilanjutkan dengan pemberian posttest pada kedua kelas sampel. Instrumen soal pretest dan posttest yang digunakan adalah soal-soal yang sama dengan urutan yang berbeda. Indikator keterampilan berpikir kritis yang terdapat dalam soal mengacu pada indikator yang dikemukakan oleh Ennis (1995), yang meliputi: memfokuskan pertanyaan, menganalisis argumen, bertanya dan menjawab pertanyaan, mempertimbangkan apakah sumber dapat dipercaya atau tidak, mengobservasi dan mempertimbangkan laporan observasi, mendeduksi dan mempertimbangkan hasil deduksi, membuat dan menentukan hasil pertimbangan, mengidentifikasi asumsi-asumsi, berinteraksi dengan orang lain, serta menentukan hasil tindakan.

Instrumen Lembar observasi berfungsi untuk mengamati ketercapaian guru dalam mengelola model pembelajaran discovery learning serta aktivitas siswa terhadap model pembelajaran yang digunakan oleh guru pada saat pembelajaran berlangsung. Lembar observasi ini dibuat dalam bentuk daftar cheklist. Jadi dalam pengisiannya, observer memberikan tanda cheklist pada tahapantahapan model pembelajaran discovery learning.

Teknik analisis data untuk instrumen tes dalam penelitian ini, yaitu dengan melakukan uji validitas dan reliabilitas. Validitas instrumen terbagi 2, yaitu validitas isi dan validitas empiris. Validitas isi ditentukan melalui pertimbangan oleh para ahli/dosen ahli. Sedangkan validitas empiris ditentukan menggunakan rumus korelasi Pearson Product Moment (PPM). Uji reliabilitas tes pada penelitian ini menggunakan rumus Alpha Cronbach.

Analisis data deskriptif dalam penelitian ini bertujuan untuk mengolah data dari hasi tes kemampuan berpikir kritis siswa pada kedua kelas sampel, yaitu data pretest dan posttest. Adapun langkah-langkah pengolahan data pretest dan posttest adalah sebagai berikut:

1. Mengelompokkan data hasil pretest dan posttest dengan rentang nilai dari terendah sampai dengan tertinggi.

2. Membuat diagram skor siswa sesuai dengan criteria interpretasi skor kemampuan berpikir kritis.

Adapun perhitungan untuk data pengolahan data pretest dan posttest dengan menggunakan rumus sebagai berikut:

$$
p=\frac{\sum_{i=1}^{n} X_{i}}{n} \times 100 \%
$$

Keterangan:

$X_{i} \quad=$ Jumlah skor

$n \quad=$ Jumlah siswa

$p \quad=$ Persentase berpikir kritis siswa 
Tabel 1. Kriteria Persentase Berpikir Kritis

\begin{tabular}{cc}
\hline Skorn-Gain & Interpretasi \\
\hline $89 \%<\mathrm{x} \leq 100 \%$ & Sangat Tinggi \\
$78 \%<\mathrm{x} \leq 89 \%$ & Tinggi \\
$64 \%<\mathrm{x} \leq 78 \%$ & Sedang \\
$55 \%<\mathrm{x} \leq 64 \%$ & Rendah \\
$0 \%<\mathrm{x} \leq 55 \%$ & SangatRendah \\
\hline
\end{tabular}

(Slameto,1996)

Keefektivan model discovery learning ditentukan dengan perhitungan n-Gain, uji normalitas, uji homogenitas, uji perbedaan rata-rata dan uji ukuran pengaruh.

Untuk mengetahui peningkatan keterampilan berpikir kritis siswa berdasarkan hasil pretest dan posttestdari kelompok sampel, dapat menggunakan perbandingan nilai Gain yang ternormalisasi (n-Gain). Adapun rumus yang digunakan adalah:

$$
n-\text { Gain }=\frac{S_{\text {postest }}-S_{\text {pretest }}}{S_{\text {maksimum }}-S_{\text {pretest }}}
$$

(Hake dalamFidiana, dkk., 2018)

Keterangan:

$n$-Gain $=$ indeks Gain ternormalisasi

$\mathrm{S}_{\text {postest }}=$ nilai awal pembelajaran

$\mathrm{S}_{\text {postest }}=$ nilai akhir pembelajaran

Selanjutnya, kriteria untuk menginterpretasi nilai $n$-Gain ditunjukkan pada Tabel 4 berikut:

Tabel 2. Kriteria $n$-Gain (g)

\begin{tabular}{cc}
\hline Skorn-Gain & Interpretasi \\
\hline $0.00<\mathrm{g}<0.30$ & Rendah \\
$0.30<\mathrm{g}<0.70$ & Sedang \\
$0.70<\mathrm{g}<1.00$ & Tinggi \\
\hline
\end{tabular}

(Sumber: Hake dalamFidianadkk., 2018)

Sebelum dilakukan pengujian hipotesis terlebih dahulu dilakukan uji normalitas sebagai uji prasyarat. Uji normalitas digunakan untuk mengetahui apakah sampel berasal dari populasi berdistribusi normal atau tidak. Uji normalitas yang digunakan adalah uji Liliefors.
Kaidah pengambilan keputusan berdasarkan distribusi tabel nilai kritis uji Liliefor suntuk taraf signifikan $\alpha$, yaitu:

Jika $\mathrm{L}_{\text {hitung }}<\mathrm{L}_{\text {tabel }}$ maka sampel berdistribusi normal.

Jika $\mathrm{L}_{\text {hitung }}>\mathrm{L}_{\text {tabel }}$ maka sampel tidak berdistribusi normal.

Uji homogenitas pada penelitian ini dilakukan untuk mengetahui apakah data yang diperoleh termasuk homogen yaitu data yang berasal dari populasi yang sama. Rumus yang digunakan adalah sebagaiberikut:

$$
F_{\text {hitung }}=\frac{\text { variansterbesar }}{\text { variansterkecil }} \quad \text { Sugiyono, 2013) }
$$

Kaidah pengambilan keputusan berdasarkan distribusi tabel $\mathrm{F}$ untuk taraf signifikan $\alpha$ dan derajat kebebasan $(\mathrm{dk})=$ $\mathrm{n}-1$, yaitu:

Jika $F_{\text {hitung }} \geq F_{\text {tabel }}$ berarti tidak homogen, tapi Jika $F_{\text {hitung }} \leq F_{\text {tabel }}$ berarti homogen.

Selanjutnya dilakukan uji perbedaan rata-rata menggunakan Independent $t$ test pihak kanan dengan asumsi peningkatan keterampilan berpikir kristis siswa kelas eksperimen lebih tinggi secara signifikan dibandingkan kelas kontrol.

$\mathrm{H}_{\mathrm{o}}$ : rata-rata $n$-Gain kelas eksperimen lebih rendah atau sama dengan rata-rata kelas kontrol. $\mathrm{H}_{\mathrm{o}}: \mu_{1} \leq \mu_{2}$

$\mathrm{H}_{\mathrm{a}}$ : rata-rata $n$-Gain kelas eksperimen lebih tinggi dari rata-rata $n$-Gain kelas kontrol. $\mathrm{H}_{\mathrm{a}}: \mu_{1}>\mu_{2}$

Dengan rumus independent t test, yaitu:

$$
\begin{gathered}
t=\frac{\bar{x}_{1-} \bar{x}_{2}}{S g a b \sqrt{\frac{1}{n_{1}}+\frac{1}{n_{2}}}} \\
\text { dengan } \mathrm{v}=\mathrm{n}_{1}+\mathrm{n}_{2}=2 \\
S^{2} g a b=\frac{\left(n_{1}-1\right) S_{1}^{2}+\left(n_{2}-1\right) S_{2}^{2}}{n_{1}+n_{2}-2} \\
\text { Keterangan: } \\
\overline{\mathrm{x}}_{1} \quad=\text { rata-rata } n \text {-Gain kelas eksperimen } \\
\overline{\mathrm{x}}_{2} \quad=\text { rata-rata } n \text {-Gain kelas kontrol } \\
n_{1} \quad=\text { banyaknya siswa kelas eksperimen } \\
\mathrm{n}_{2} \quad=\text { banyaknya siswa kelas kontrol }
\end{gathered}
$$

Keterangan: 
$S g a b=$ simpangan baku gabungan

Kaidah pengambilan keputusan untuk uji hipotesis statistik berdasarkan distribusi table $t$ dengan taraf signifikan yang digunakan $\alpha=$ 0.05 dan derajat kebebasan $(\mathrm{dk})=\mathrm{n}_{1}+\mathrm{n}_{2}-2$, yaitu sebagai berikut:

Jika $t_{\text {hitung }} \leq t_{\text {tabel }}$, maka $\mathrm{H}_{0}$ diterima dan $\mathrm{Ha}$ ditolak

Jika $t_{\text {hitung }}>t_{\text {tabel }}$, maka $\mathrm{H}_{0}$ ditolak dan $\mathrm{Ha}$ diterima

Selanjutnya dilakukan perhitungan untuk mengetahui seberapa besar pengaruh model discovery learning dalam meningkatkan keterampilan berpikir kritis siswa maka dilakukan uji ukuran pengaruh (effect size) dengan rumus Cohen's $d$ sebagai berikut:

Keterangan:

$$
d=\frac{\bar{x}_{1}-\bar{x}_{2}}{S_{g a b}}
$$

$d \quad=$ Effect Size

$\bar{x}_{1} \quad=$ rata-rata $n$-Gain kelas eksperimen

$\bar{x}_{2} \quad=$ rata-rata $n$-Gain kelas kontrol

$S_{g a b}=$ simpangan baku gabungan

Adapun kriteria klasifikasi interpretasi nilai $d$ pada uji ukuran pengaruh adalah sebagai berikut:

Tabel 3. Kriteria Ukuran Pengaruh (Effect Size)

\begin{tabular}{cc}
\hline Ukuran Pengaruh & Kriteria \\
\hline $0,2 \leq d \leq 0,5$ & Efek kecil \\
$0,5 \leq d \leq 0,8$ & Efek sedang \\
$0,8 \leq d \leq 2,0$ & Efek besar \\
\hline
\end{tabular}

Analisis lembar observasi digunakan untuk mengetahui keterlaksanaan model pembelajaran discovery learning yang dilihat dari tingkat ketercapaian guru dalam mengelola pembelajaran serta aktivitas siswa. Rumus yang digunakan adalah sebagai berikut:

Keterangan:

$$
\% J i=\frac{\sum j_{i}}{N} \times 100 \%
$$

$\% J i=$ Persentase dari skor ideal untuk setiap aspek pengamatan pada pertemuan ke$i$

KATALIS Jurnal Penelitian Kimia dan Pendidikan Kimia

Vol. 3, No.1, Juni 2020
$\Sigma J i=$ Jumlah skor setiap aspek pengamatan yang diberikan oleh pengamat pada pertemuan ke- $i$

$\mathrm{N}=$ Skor maksimal (skor ideal)

Adapun kriteria klasifikasi interpretasi persentase pada analisis lembar observasi adalah sebagai berikut:

Tabel 4. Kriteria Tingkat Ketercapaian

\begin{tabular}{cc}
\hline Persentase & Kriteria \\
\hline $80,1 \%-100,0 \%$ & Sangat baik \\
$60,1 \%-80,0 \%$ & Baik \\
$40,1 \%-60,0 \%$ & Sedang \\
$20,1 \%-40,0 \%$ & Kurang \\
$0,0 \%-20,0 \%$ & Sangat kurang \\
\hline
\end{tabular}

(Sumber: Fidiana dkk., 2018)

\section{HASIL DAN PEMBAHASAN}

\section{Efektivitas Model Pembelajaran Discovery Learning untuk Meningkatkan Keterampilan Berpikir Kritis Siswa}

Keefektivan model discovery learning terhadap peningkatan keterampilan berpikir kritis dalam penelitian ini diperoleh dari analisis data $n$-Gain. Data untuk mengukur tingkat keterampilan berpikir kritis siswa pada kelas XI IPA 1 dan XI IPA 2 di MAN 1 Langsa diperoleh dengan cara melakukan pretest dan posttest. Hasil dari rata-rata nilai pretes dan postes ditunjukkan pada Gambar 1 berikut:

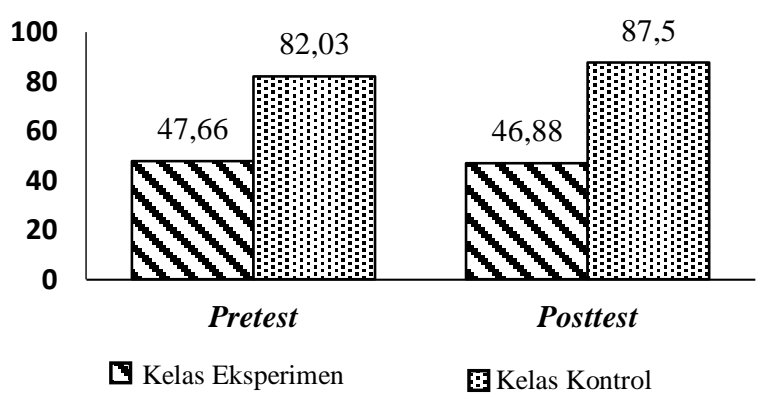

\section{Gambar 1. Perbandingan Nilai Rata-Rata Pretestdan Posttest}

Berdasarkan Gambar 1, rata-rata nilai pretest dan posttest keterampilan berpikir kritis siswaa terjadi peningkatan rata-rata nilai siswa sebelum (pretest) da sesudah (postest) pelaksanaan pembelajaran dengan 
model discovery learning. Artinya penggunaan model pembelajaran discovery learning meningkatkan nilai rata-rata keterampilan berpikir kritis siswa lebih tinggi dari yang tanpa menggunakan model pembelajaran discovery learning.

Dari hasil perhitungan $n$-Gain, nilai ratarata yang diperoleh siswa kelas eksperimen sebesar 0,77, artimya kelas eksperimen mempunyai peningkatan keterampilan berpikir kritis yang tergolong kedalam kategori tinggi menurut kriteria Hake dalam Fidiana dkk. (2018). Sedangkan rata-rata $n$-Gain siswa kelas kontrol sebesar 0,66, artinya kelas kontrol mempunyai peningkatan keterampilan berpikir kritis yang tergolong kedalam kategori sedang, maka dapat disimpulkan bahwa peningkatan keterampilan berpikir kritis siswa yang menggunakan model pembelajaran discovery learning lebih tinggi daripada siswa pada kelas yang tidak menggunakan model pembelajaran discovery learning.

Dari hasil pengujian normalitas data $n$ gain dengan jumlah sampel masing-masing sebanyak 20 siswa dan taraf signifikansi $(\alpha)=$ 0,05 diperoleh nilai $L_{\text {hitung }}=0,112$ dan $L_{\text {tabel }}=$ 0,190. $L_{\text {hitung }}<L_{\text {tabel }}$, maka Ho diterima, sehinggadapat disimpulkan bahwa data $n$-Gain kedua kelompok sampel tersebut berdistribusi normal.

Dari hasil uji homogenitas yang dilakukan dengan uji $\mathrm{F}$ dengan taraf signifikansi $(\alpha)=0,05$ dan derajat kebebasan $d k=\mathrm{n}-1$, diperoleh $\mathrm{F}_{\text {hitung }}<\mathrm{F}_{\text {tabel }}$ atau 1,79< 2,17 sehingga Ho diterima, dengan demikan dapat disimpulkan bahwa varians dari data $n$ Gain kelas eksperimen dan kelas control adalah homogeny (sama) atau dapat mewakili seluruh populasi yang ada.

Dari hasil perhitungan uji hipotesis dengan taraf signifikansi 0,05 dan df $=38$, diperoleh $t_{\text {hitung }} \geq t_{\text {tabel }}(2,89 \geq 1,68)$ maka Ho ditolak dan $\mathrm{H}_{\mathrm{a}}$ diterima. Sehingga dapat disimpulkan rata-rata $n$-Gain kelas eksperimen lebih tinggi dibandingkan rata-rata n-Gain kelas kontrol, atau dengan kata lain peningkatan keterampilan berpikir kritis siswa kelas eksperimen lebih tinggi secara signifikan dibandingkan peningkatan keterampilan berpikir kritis siswa kelas kontrol.

Analisis terhadap data $n$-Gain, telah menjawab salah satu masalah yang diajukan dalam penelitian ini yaitu keterampilan berpikirkritis siswa pada kelas eksperimen yang menggunakan model pembelajaran discovery learning mengalami peningkatan yang signifikandibandingkan peningkatan keterampilan berpikir kritis siswa pada kelas kontrol. Untuk mengetahui pengaruh model pembelajaran discovery learning dalam meningkatkan keterampilan berpikir kritis siswa dilakukan dengan pengujian effect size, harga $d$ yang diperoleh yaitu sebesar 0,96 yang tergolong ke dalam kategori efek besar menurut criteria Dincer (dalam Fidiana, 2018).

Berdasarkan hasil interpretasi nilai $n$ Gain, uji perbedaan rata-rata, dan uji ukuran pengaruh, maka dapat disimpulkan proses pembelajaran dengan menggunakan model pembelajaran discovery learning lebih efektif dalam meningkatkan keterampilan berpikir kritis pada materi sistem koloid dibandingkan pembelajaran yang tidak menggunakan model pembelajaran discovery learning. Hasil penelitian ini sejalan dengan penelitian yang dilakukan oleh Nugrahaeni, Redhana, dan Kartawan (2017) serta Triono, Santoso, dan Su'ud (2018) yang menyatakan bahwa penerapan pembelajaran dengan menggunakan model discovery learning terbukti efektif dalam meningkatkan keterampilan berpikir kritis dan hasil belajar kimia siswa. Palupi dkk. (2018) juga menyatakan bahwa penerapan model discovery learning terbukti efektif dalam meningkatkan keterampilan berpikir kritis dan hasil belajar kimia siswa. Palupi dkk. (2018) juga menyatakan bahwa penerapan model discovery learning dapat meningkatkan kemampuan berpikir kritis siswa pada pembelajaran kimia pada materi hidrolisis bermuatan etnosains. Selain itu, Rudibyani (2018) menyatakan bahwa model discovery learning efektif dalam meningkatkan kemampuan berpikir kritis siswa pada materi asam-basa arrhenius. 
Menurut Lestari dan Utami (2017), model discovery learning dapat meningkatkan keterampilan berpikir kritis karena discovery learning adalah pembelajaran yang berfokus pada konsep-konsep dan prinsip-prinsip utama (sentral) dari suatu disiplin, melibatkan siswa secara aktif dalam kegiatan pemecahan masalah dan tugas-tugas bermakna lainnya.

\section{Keterlaksanaan Model Pembelajaran oleh Guru dan Siswa}

Kemampuan guru dalam mengelola pembelajaran dengan model discovery learning ditunjukkan pada Tabel 8.

\section{Tabel 5. Deskripsi Hasil Observasi} Ketercapaian Guru

\begin{tabular}{lccc}
\hline \multirow{2}{*}{ AspekPengamatan } & \multicolumn{3}{c}{ Keterlaksanaan (\%) } \\
\cline { 2 - 4 } & Pert 1 & Pert 2 & Pert3 \\
\hline Stimulation & 42,8 & 50 & 64,3 \\
Problem statement & 50 & 50 & 50 \\
\hline Data collecting & 100 & 100 & 100 \\
Data processing & 50 & 75 & 100 \\
Verification & 100 & 100 & 100 \\
Generalization & 100 & 100 & 100 \\
\hline Rata-rata tiappertemuan & $\mathbf{7 3 , 8 0}$ & $\mathbf{7 9 , 1 0}$ & $\mathbf{8 5 , 7 0}$ \\
\hline
\end{tabular}

Berdasarkan data diatas dapat dilihat bahwa hasil pengamatan ketercapaian guru terhadap keterlaksanaan model pembelajaran discovery learning diperoleh nilai rata-rata pada pertemuan pertama yaitu sebesar 73,80 tergolong kedalam kriteria baik. Pada pertemuan kedua diperoleh nilai rata-rata yaitu sebesar 79,10 tergolong kedalam kriteria baik, dan pada pertemuan ketiga diperoleh nilai rata-rata yaitu sebesar 85,70 tergolong kedalam kriteria baik. Sehingga dapat disimpulkan bahwa keterlaksanaan pembelajaran menggunakan model pembelajaran discovery learning yaitu termasuk kedalam kriteria baik. Hasil pengamatan terhadap keterlaksanaan pembelajaran oleh guru ini menunjukkan bahwa guru sudah melaksanakan pembelajaran sesuai dengan langkah-langkah dari model pembelajaran discovery learning berdasarkan RPP yang telah disusun sebelumnya. Namun, pelaksanaan pembelajaran masih belum terlaksana secara keseluruhan karena masih ada beberapa aspek yang belum dilakukan oleh guru.

\section{Tabel 6. Deskripsi Hasil Observasi} Aktivitas Siswa

\begin{tabular}{lccc}
\hline \multirow{2}{*}{ AspekPengamatan } & \multicolumn{3}{c}{ Keterlaksanaan (\%) } \\
\cline { 2 - 4 } & Pert 1 & Pert 2 & Pert 3 \\
\hline Stimulation & 100 & 100 & 66,6 \\
Problem statement & 100 & 100 & 100 \\
Data collecting & 100 & 50 & 100 \\
Data processing & 100 & 100 & 100 \\
Verification & 100 & 100 & 100 \\
Generalization & 100 & 100 & 100 \\
\hline Rata-rata tiappertemuan & $\mathbf{1 0 0}$ & $\mathbf{9 1 , 7 0}$ & $\mathbf{9 4 , 4 3}$ \\
\hline
\end{tabular}

Berdasarkan data diatas dapat dilihat bahwa hasil pengamatan aktivitas siswa terhadap model pembelajaran discovery learning diperoleh nilai rata-rata pada pertemuan pertama yaitu sebesar 100 tergolong kedalam kriteria sangat baik. Pada pertemuan kedua diperoleh nilai rata-rata yaitu sebesar 91,70 tergolong kedalam kriteria sangat baik, dan pada pertemuan ketiga diperoleh nilai rata-rata yaitu sebesar 94,43 tergolong kedalam kriteria sangat baik. Sehingga dapat disimpulkan bahwa keterlaksanaan pembelajaran menggunakan model pembelajaran discovery learning yaitu termasuk kedalam kriteria sangat baik. Sehinggadapat disimpulkan bahwa keterlaksanaan pembelajaran menggunakan model pembelajaran discovery learning yaitu termasuk ke dalam kriteria sangat baik. Hasil pengamatan terhadap keterlaksanaan pembelajaran oleh siswa ini menunjukkan bahwa dengan menerapkan model pembelajaran discovery learning, siswa menjadi lebih aktif dan mandiri dalam menyelesaikan suatu masalah.

\section{KESIMPULAN}

Berdasarkan hasil penelitian dan pembahasan yang telah dilakukan, maka dapat disimpulkan bahwa:

1. Pembelajaran dengan menggunakan model discovery learning lebih efektif dibandingkan pembelajaran yang tidak menggunakan model pembelajaran 
discovery learning dalam meningkatkan keterampilan berpikir kritis siswa pada materi sistem koloid. Hal ini ditunjukkan melalui hasil perolehan nilai $n$-Gain, uji perbedaan rata-rata, dan uji ukuran pengaruh (effect size).

a. Hasil nilai $n$-Gain pada kelas eksperimen dan kelas kontrol yaitu 0,77 dan 0,66 , yang artinya peningkatan keterampilan berpikir kritis siswa pada kelas eksperimen tergolong dalam kriteria tinggi dan kelas kontrol tergolong dalam kriteria sedang.

b. Hasil uji perbedaan rata-rata untuk nilai $t_{\text {hitung }} \geq t_{\text {tabel }} \quad(2,89 \geq 1,68)$, sehingga $H_{0}$ ditolak, yang artinya peningkatan keterampilan berpikir kritis siswa pada kelas eksperimen lebih tinggi secara signifikan dibandingkan siswa pada kelas kontrol.

c. Hasil analisis ukuran pengaruh (effect size) menunjukkan bahwa nilai $\mu$ yang diperoleh sebesar 0,96 yang artinya efek model discovery learning terhadap peningkatan keterampilan berpikir kritis siswa tergolong kedalam kriteria besar.

2. Keterlaksanaan model pembelajaran discovery learning oleh guru pada materi sistem koloid di XI IPA MAN 1 Langsa menunjukkan bahwa pada pertemuan pertama yaitu sebesar 73,80, pada pertemuan kedua sebesar 79,10, dan pada pertemuan ketiga sebesar 85,70 yang ketiga pertemuan tergolong kedalam kriteria baik.

3. Keterlaksanaan model pembelajaran discovery learning oleh siswa pada materi sistem koloid di XI IPA MAN 1 Langsa menunjukkan bahwa pada pertemuan pertama yaitu sebesar 100, pada pertemuan kedua sebesar 91,70 dan pada pertemuan ketiga sebesar 94,43 yang ketiga pertemuan tergolong kedalam kriteria sangat baik.

\section{UCAPAN TERIMA KASIH}

Penulis mengucapkan rasa terimakasih yang sebesar-besarnya kepada kepala sekolah, guru, dan staf administrasi MAN 1 Langsa yang telah membantu.

\section{DAFTAR PUSTAKA}

Ariani, Y., Rasmiwetti, \& Haryati, S. 2018. Penerapan Model Pembelajaran Somatis, Auditori, Visual, Intelektual (SAVI) pada Materi Koloid untuk Meningkatkan Kemampuan Berpikir Kritis Siswa di Kelas XI MIA SMAN 2 Bangkinang Kota. JOM FKIP. Vol. 5

Arifin, Z. 2017. Mengembangkan Instrumen Pengukur Critical Thinking Skills Siswa pada Pembelajaran Matematika Abad 21. Jurnal THEOREMS (The Original Research of Mathematics). Vol. 1, No. 2, Hal. 92-100.

Arikunto, S. 2013. Prosedur Penelitian Suatu Pendekatan Praktik. Jakarta: Rineka Cipta.

Arikunto, S. 2017. Dasar-Dasar Evaluasi Pendidikan. Jakarta: Bumi Aksara.

Bruner, J.S. 1997. Collaborative Discovery Learning of Model Design. Berlin: Springerperlag.

Ennis, R.H. 1995. Critical Thinking. New York: Prentice Hall.

Facione, P.A., Sánchez, C.A., Facione, N.C., \& Gainen, J. 2010. The Disposition Toward Critical Thinking. Journal of General Education. Vol. 44 No.1, Hal. 1-25.

Fidiana, E., Rudibyani, R.B., \& Tania, L. 2018. Penerapan Discovery Learning untuk Meningkatkan Keterampilan Berpikir Luwes Materi Larutan Penyangga. Jurnal Pendidikan dan Pembelajaran Kimia. Vol. 7, No.1, Hal. 104-115.

Hidayah, Salimi, M., \&Susiani, T.S. 2017. Critical Thinking Skill: Konsep dan Indikator Penilaian. Jurnal Taman Cendekia, Vol. 01, No. 02. 
Kristaliningtyas, B., Utomo, S.B., \& Yamtinah, S. 2018. Penerapan Model Pembelajaran Cooperative Script untuk Meningkatkan Kemampuan Memahami Bacaan dan Prestasi Belajar pada Materi Pokok Hidrolisis Garam SMA Negeri 1 Ngemplak Tahun Pelajaran 2016/2017. Jurnal Pendidikan Kimia. Vol. 7, No. 2, Hal. 236-243.

Llyod, M., \& Bahr, N. 2010. Thinking Critically About Critical Thinking in Higher Education. International Journal for The Scholarship of Teaching and Learning. Vol.4, No.2, Hal. 1-16.

Masrida, Hala, Y., \& Taiyeb, A.M. 2016. Pengaruh Model Pembelajaran Discovery terhadap Keterampilan Berpikir Kritis dan Hasil Belajar IPA Kelas VIII MTSN Libureng Kabupaten Bone. Jurnal Bionature. Vol.17, No.2, Hal. 81-87.

Muslim, I., Halim. A., \& Safitri, R. 2015. Penerapan Model Pembelajaran PBL untuk Meningkatkan Penguasaan Konsep dan Keterampilan Berpikir Kritis Siswa pada Konsep Elastisitas dan Hukum Hooke di SMA Negeri Unggul Harapan Persada. Jurnal Pendidikan Sains Indonesia. Vol. 03, No.02, Hal. 35-50

Muin, A. 2018. Membangun Critical Thinking Skill: Tagihan Kompetensi Abad 21. I'TIBAR (Jurnal Ilmiah Ilmu-Ilmu Keislaman). Vol. 06, No. 11.

Nugrahaeni, A., Redhana, I.W., \& Katawan, I.M. 2017. Penerapan Model Pembelajaran Discovery Learning untuk Meningkatkan Kemampuan Berpikir Kritis dan Hasil Belajara Siswa. Jurnal Pendidikan Kimia Indonesia. Vol. 1, No. 1, Hal 23-29.

Palupi, M.D., Sudarmin, \& Wardani, S. 2018. Penerapan Discovery learning untuk Meningkatkan Kemampuan Berpikir
Kritis pada Pembelajaran Bermuatan Etnosains. Journal Chemistry in Education. Vol.1, No.7, Hal.77-83.

Pratiwi, F.A., Hairida, \& Rasmawan, R. 2014. Pengaruh Penggunaan ModelDiscovery Learning dengan Pendekatan Saintifik terhadap Keterampilan Berpikir Kritis Siswa SMA. Artikel Penelitian: 2-4.

Purba, M.N., Rosilawati, I., \& Efkar, T. 2016. Efektivitas Discovery Learning pada Materi Koloid dalam Meningkatkan Keterampilan Mengelompokkan dan Mengomunikasikan. Jurnal Pendidikan dan Pembelajaran Kimia. Vol. 5, No. 3.

Purwanto, C.E. 2012. Penerapan Model Pembelajaran Guided Discovery pada Materi Pemantulan Cahaya untuk Meningkatkan Berpikir Kritis. Unnes Physics Education Journal. Vol. 1, No.1, Hal. 64-66.

Rudibyani, R.B. 2018. The Effectiveness of Discovery learning to Improve Critical Thingking Skil College Students on Mastery of Arrhenius Acid Base. Science, Engineering, Education, and Development Studies (SEEDs:Conference Series. Vol. 2, No.1, Hal. 41-54.

Sugiyono. 2013. Metode Penelitian Kuantitatif, Kualitatif, dan $R \& D$. Bandung: Alfabeta.

Sugiyono. 2018. Metode Penelitian Kuantitatif, Kualitatif, dan $R \& D$. Bandung: Alfabeta.

Triono, A., Santoso, \& Su'ad. 2018. The Effect of Discovery learning Model on Critical Thingking Ability in Thematic Learning. International Conference Education, Culture an Technology. Vol. 1, No. 1, Hal. 9598. 
e-ISSN: 2721-9038

p-ISSN: 2721-902X

Watoni,dkk. 2016. KIMIA untuk Siswa SMA/MA Kelas XI. Bandung: Yrama Widya

Yasushi, G. 2016. Development of Critical Thinking With Metacognitive Regulation. International Conference on Cognition and Exploratory Learning in Digital Age (CELDA 2016): Niigata University. 